\title{
Review \\ Nanoparticle-Based Modification of the DNA Methylome: A Therapeutic Tool for Atherosclerosis?
}

\author{
Ana Cristina Márquez-Sánchez ${ }^{1}$, Lino Sánchez-Segura ${ }^{2}$ (D) , Gertrud Lund ${ }^{2}$ and Silvio Zaina ${ }^{1, *(1)}$ \\ 1 Department of Medical Sciences, Division of Health Sciences, Leon Campus, University of Guanajuato, \\ Leon 37320, GTO, Mexico; a.mrquezs@gmail.com \\ 2 Department of Genetic Engineering, CINVESTAV Irapuato Unit, Irapuato 36824, GTO, Mexico; \\ lino.sanchez@cinvestav.mx (L.S.-S.); gertrud.lund@cinvestav.mx (G.L.) \\ * Correspondence: szaina@ugto.mx
}

check for

updates

Citation: Márquez-Sánchez, A.C.;

Sánchez-Segura, L.; Lund, G.; Zaina, S. Nanoparticle-Based Modification of the DNA Methylome:

A Therapeutic Tool for

Atherosclerosis? Cardiogenetics 2022,

12, 12-23. https://doi.org/10.3390/ cardiogenetics 12010002

Academic Editor: George E.

Louridas

Received: 25 October 2021

Accepted: 31 December 2021

Published: 6 January 2022

Publisher's Note: MDPI stays neutral with regard to jurisdictional claims in published maps and institutional affiliations.

Copyright: () 2022 by the authors Licensee MDPI, Basel, Switzerland. This article is an open access article distributed under the terms and conditions of the Creative Commons Attribution (CC BY) license (https:/ / creativecommons.org/licenses/by/ $4.0 /)$.

\begin{abstract}
Cardiovascular epigenomics is a relatively young field of research, yet it is providing novel insights into gene regulation in the atherosclerotic arterial wall. That information is already pointing to new avenues for atherosclerosis (AS) prevention and therapy. In parallel, advances in nanoparticle (NP) technology allow effective targeting of drugs and bioactive molecules to the vascular wall. The partnership of NP technology and epigenetics in AS is just beginning and promises to produce novel exciting candidate treatments. Here, we briefly discuss the most relevant recent advances in the two fields. We focus on AS and DNA methylation, as the DNA methylome of that condition is better understood in comparison with the rest of the cardiovascular disease field. In particular, we review the most recent advances in NP-based delivery systems and their use for DNA methylome modification in inflammation. We also address the promises of DNA methyltransferase inhibitors for prevention and therapy. Furthermore, we emphasize the unique challenges in designing therapies that target the cardiovascular epigenome. Lastly, we touch the issue of human exposure to industrial NPs and its impact on the epigenome as a reminder of the undesired effects that any NP-based therapy must avoid to be apt for secondary prevention of AS.
\end{abstract}

Keywords: atherosclerosis; bioactive molecule delivery; drug delivery; epigenetics; DNA methylation; nanoparticle

\section{Introduction}

Drug loading to nanoparticles (NPs) allows targeting to specific cells and tissues and generally increases drug potency. The latter is achieved by combinations of improved biodistribution, solubility, site-release characteristics, circulation half-life, bioavailability, and immunogenicity (for a recent general review of the topic, see [1]). An additional often-mentioned phenomenon that enhances NP effectiveness is enhanced permeability and retention (EPR). EPR refers to the tendency of NPs to accumulate at sites of poor endothelial barrier, as consequence of either abnormal angiogenesis or endothelial damage. Although a controversial concept, EPR has been documented in cancer. Conversely, the relevance of EPR in cardiovascular disease is not well understood [2].

In recent years, NP technology and epigenetics have joined forces to pursue novel therapeutic strategies for human disease. Epigenetic marks are covalent chemical modifications of histones and DNA that are generally reversible [3]. The best understood epigenetic modification of DNA is methylation, the focus of this article. DNA methylation (DNAm) is catalysed by the DNA methyltransferase (DNMT) enzyme family [4]. DNMT target mainly cytosine in a 5'-CG-3' context in mammals, resulting in the formation of 5-methyldeoxycytosine ( $5 \mathrm{mC})$. In turn, loss of DNAm can occur passively-when DNMT activity is surpassed by the cell proliferation rate-or by active mechanisms that involve $5 \mathrm{mC}$ oxidation and DNA repair to reinstate the original cytosine. DNA methylation 
regulates gene expression in a context-dependent manner. For example, gene promoter DNA methylation generally leads to transcriptional silencing. Cellular DNAm profiles are tightly regulated during differentiation and participate in establishing tissue-specific gene expression, but stochastic changes in DNAm due to epigenetic drift also occur [5-7].

Here, we briefly review the most recent (published in 2019-present) advances in the quest of NP-based strategies to modify the DNA methylome of atherosclerosis (AS). We keep a narrow focus on AS, as the DNA methylome of that condition is better described in comparison with the rest of the cardiovascular field. The literature was chosen among entries obtained by PubMed email alert with the 'nanoparticle atherosclerosis' and 'nanoparticle' search terms.

\section{Atherosclerosis: The Essentials}

Rudolph Virchow's seminal work proposed that AS is an inflammatory disease of the artery almost two centuries ago [8]. AS is promoted by endothelial dysfunction and accumulation of lipoproteins, some of which undergo oxidation, into the vascular wall. In particular, small apolipoprotein B-containing low-density lipoprotein particles have been identified as highly atherogenic [9]. These early events are followed by infiltration of monocyte-derived macrophages, an inflammatory response aimed at scavenging excess vascular wall oxidized lipoproteins [10]. Lipid-loaded macrophages are referred to as foam cells. While the conditions that promote AS persist, the vascular inflammatory response fails to resolve. The resulting chronic inflammation is accompanied by discontinuous growth of the atheroma, a phenomenon that spans decades in humans [11]. The expansion of the atheroma is driven by sustained macrophage and other immune cell recruitment and migration of smooth muscle cells (SMC) from the underlying media. SMC are critical players in AS: they differentiate from contractile, quiescent cells specialized in maintaining blood pressure homeostasis, to synthetic cells capable of migration, proliferation, and extracellular matrix synthesis [12]. Additionally, cell lineage tracking indicates that the majority of foam cells in the atheroma derive from SMC [13]. These events lead to the formation of a lipid-rich fibrocellular lesion (atheroma). Single-cell phenotype analysis revealed the presence of at least 14 cell types in the atheroma, including the endothelium, both antiinflammatory and proinflammatory macrophages, a variety of myeloid and lymphoid cells, SMC, and significant cellular interconversion-i.e., endothelial to mesenchymal transition or vice versa, and SMC displaying macrophage markers [14]. The atheroma eventually undergoes rupture in a minority of atheroma-bearing individuals, causing thrombosis that leads to the three main clinical complications of AS: myocardial infarction, stroke, and peripheral vascular disease [15]. Risk factors for AS include diabetes, hyperlipidaemia, hypertension age, male sex, and smoking, in addition to genetic predisposition and the accumulation of somatic mutations during haematopoiesis [16-18].

\section{The DNA Methylome of AS}

DNAm is altered in AS and in virtually any disease. Disease-specific DNAm profiles are imposed by a combination of dietary, lifestyle-related, and environmental factors and stochastic mechanisms [9]. The epigenetics of AS is a relatively young but rapidly expanding field, thanks to increasingly affordable sequencing and high-coverage microarray platforms. The latter include the Illumina Infinium HumanMethylation27 BeadChip, HumanMethylation450 BeadChip Kit, and, more recently, the Infinium MethylationEPIC Kit microarrays (containing 27,000, 450,000, and 850,000 CpG probes, respectively) [19,20]. The rapid pace of research is already pointing to plausible NP-based strategies for the delivery of drugs that target the vascular epigenome. From a general viewpoint, such novel therapies for AS promise to lower the residual cardiovascular risk-i.e., the risk that persists after normalizing blood lipid levels with drugs such as statins or fibrates [21]. Indeed, it has been suggested that AS could be an orphan disease if adult human blood lipid levels were the same as in newborns or non-primate mammals [22]. From a molecular viewpoint, epigenetic studies may identify AS-associated DNAm profiles, either inherited 
or acquired following exposure to risk factors. Observations from multiple independent studies suggest that DNA hypermethylation is a landmark and, importantly, a driver of AS. The comparison of human DNA methylomes of atherosclerotic and healthy vascular samples matched for artery type and donor revealed widespread DNA hypermethylation across the genome [23]. DNA hypermethylation is likely to be established at very early stages of AS or even before any detectable histological evidence of atheroma [24]. Furthermore, DNA hypermethylation increases with AS progression [25]. Accordingly, ten-eleven translocation 2 (TET2), a DNA dioxygenase that favours DNA demethylation, inhibits AS [26]. Notably, TET2 promoter hypomethylation coincides with global loss of DNA methylation and decrease of inflammatory markers in post-rupture human atheroma [27]. Mechanistically, systemic administration of DNAm inhibitors decreases the size of aortic atheromas in mice models of AS and hyperlipidaemia [28-30]. From a molecular perspective, DNAm inhibitors increase expression of antiatherogenic genes such as phosphatase and tensin homolog, liver $\mathrm{X}$ receptor, and peroxisome proliferator-activated receptor gamma and decrease proinflammatory cytokines. In the latter animal studies, the duration of the protocol was too short to thoroughly assess any adverse effects of systemic DNAm inhibitor administration.

In the following paragraphs, we summarize candidate NP delivery systems able to target the DNA methylome of AS. Furthermore, although no NP-based strategy to modify the epigenome of AS has been reported to date apart from curcumin-loaded NPs (see below), we briefly review advances in the use of NPs in the AS-related field of general inflammation.

\section{Possible NP-Based Strategies for the Modification of the AS DNA Methylome}

A synopsis of the three main features of DNA methylome-targeting NPs discussed in this section-cargo molecules, core NP materials, and specific cell type-targeting molecules is presented in Table 1.

Table 1. Synopsis of candidate and tested NP delivery systems for DNA methylome targeting in AS.

\begin{tabular}{|c|c|c|c|}
\hline & & $\begin{array}{c}\text { Advantages/Limitations or Main } \\
\text { Functional Features }\end{array}$ & References \\
\hline \multirow{4}{*}{ Core NP structure } & Liposome & $\begin{array}{l}\text { Well-characterized, comparatively easy to } \\
\text { assemble, good in vivo tolerance. }\end{array}$ & [31-33] \\
\hline & $\begin{array}{l}\text { Macrophage } \\
\text { membrane-coated }\end{array}$ & $\begin{array}{l}\text { Mimic a physiological structure. Effective } \\
\text { targeting through macrophage-atheroma } \\
\text { interactions. }\end{array}$ & [34] \\
\hline & $\begin{array}{c}\text { Platelet } \\
\text { membrane-coated }\end{array}$ & $\begin{array}{l}\text { Mimic a physiological structure. Effective } \\
\text { targeting through platelet-atheroma interactions. }\end{array}$ & {$[35,36]$} \\
\hline & Pluronic & $\begin{array}{l}\text { Foam suppressant. Long-term in vivo tolerance to } \\
\text { be determined. }\end{array}$ & [37] \\
\hline \multirow{5}{*}{ DNMT inhibitor cargo } & Curcumin & $\begin{array}{l}\text { Extremely well-characterized molecule, with a } \\
\text { range of documented biological effects, including } \\
\text { DNMT inhibition. }\end{array}$ & {$[38,39]$} \\
\hline & DNMT siRNA & Potentially highly specific. & - \\
\hline & DNMTi & $\begin{array}{l}\text { Several DNMTi available, some well-characterized } \\
\text { in cancer therapy. }\end{array}$ & {$[40]$} \\
\hline & Statins & Well-characterized cardiovascular drugs. & {$[31]$} \\
\hline & $\begin{array}{l}\text { Unknown plant-derived } \\
\text { factor(s)? }\end{array}$ & A potential abundant source of novel drugs. & - \\
\hline
\end{tabular}


Table 1. Cont.

\begin{tabular}{|c|c|c|c|}
\hline & & $\begin{array}{l}\text { Advantages/Limitations or Main } \\
\text { Functional Features }\end{array}$ & References \\
\hline \multirow{4}{*}{$\begin{array}{l}\text { Targeting system, } \\
\text { non-peptidic }\end{array}$} & Anti-PECAM-1 antibody & $\begin{array}{l}\text { Relatively expensive reagent. Binds to the } \\
\text { cellular adhesion receptor PECAM-1/CD31. }\end{array}$ & [41] \\
\hline & Apo-AI & $\begin{array}{l}\text { Physiological component of lipoproteins, } \\
\text { easy to assemble into NP. Binds to the } \\
\text { macrophage scavenger BI receptor. }\end{array}$ & [42] \\
\hline & Hyaluronic acid & $\begin{array}{l}\text { Well-characterized, good in vivo tolerance. } \\
\text { Targets the atheroma by binding to CD } 44 .\end{array}$ & {$[43,44]$} \\
\hline & Mannose & $\begin{array}{l}\text { Well-tolerated. Targets the atheroma by } \\
\text { binding to } \mathrm{M} 2 \text { macrophage } \\
\text { mannose receptor. }\end{array}$ & [45] \\
\hline \multirow{5}{*}{ Targeting peptides } & p5RHH & $\begin{array}{l}\text { Receptor-independent cell penetration. } \\
\text { Possible issues with cell type specificity. }\end{array}$ & [46] \\
\hline & cRGD & Targets integrin. & [37] \\
\hline & Lyp-1 & $\begin{array}{l}\text { Targets the foam cell-stage macrophage } \\
\text { p32 receptor. }\end{array}$ & [33] \\
\hline & PP1 & $\begin{array}{l}\text { Well-characterized, targets both human and } \\
\text { mouse scavenger AI receptor. }\end{array}$ & [47] \\
\hline & $\mathrm{S} 2 \mathrm{P}$ & $\begin{array}{l}\text { Targets stabilin-2, an endothelial } \\
\text { scavenger receptor. }\end{array}$ & {$[48]$} \\
\hline
\end{tabular}

Abbreviations: Apo-AI, apolipoprotein AI; DNMTi, DNMT inhibitor; PECAM-1, Endothelial Cell Adhesion Molecule Plate 1; S2P, stabilin-2 peptide; siRNA, small interfering RNA. Other peptide acronyms were not described in the original publications.

\subsection{Candidate NP Cargo Molecules}

The above-mentioned experimental advances in the description of the AS DNA methylome hint at possible NP-based epigenome targeting strategies. One interesting target is type 1 DNMT (DNMT1). Among other convincing evidence, mouse studies have detected epigenetic deregulation of the DNMT1-peroxisome proliferator-activated receptor (PPAR) gamma pathway in AS [28]. Vascular DNMT1 inhibition may be achieved by loading DNMT inhibitors (DNMTi) to NP that are functionalized with available endothelium or macrophage surface ligands [21]. A battery of non-nucleoside DNMTi exist, such as RG108, SGI-1027, hydralazine, (-)-Epigallocatechin-3-gallate, and others (see, for example [49]).

In addition to biochemical inhibition by means of DNMTi, DNMT1 silencing by small interfering RNAs (siRNAs) is an obvious approach. Although to our knowledge DNMT1 siRNAs encapsulated in NPs have not been employed in vascular biology, the feasibility of that approach is clearly illustrated by the effectiveness of the chemically close microRNA (miRNA)-loaded NPs. In a notable example, gold NPs functionalized with a nuclear localization signal were loaded with a siRNA specific for a miR-211 and AS1411, an anticancer drug, effectively inhibited the nuclear factor kappa B-DNMT1 signalling pathway, and promoted DNA hypomethylation in an animal model of leukaemia [50]. Another study aimed to alter macrophage cholesterol efflux by activating reverse cholesterol transport and subsequently inhibit atheroma lipid accumulation and growth in a mouse model. NPs based on the polysaccharide chitosan loaded with miR-206 or miR-223 promoted the expression of ATP binding cassette subfamily A member 1, a crucial cholesterol efflux pump [51].

Moreover, statins are universally known as effective blood cholesterol-lowering drugs but have been attributed an additional activity as epigenetic modifiers. A number of studies documented inhibition of DNMT activity and both inhibition and stimulation of histone deacetylases by statins (listed in [52]). Histone deacetylases participate in transcriptional control and regulation of metabolism [3]. Although these observations could explain the 
anti-cancer activity of statins, a recent survey disputes those conclusions [52]. Despite the current controversy, statin-loaded NPs, mostly liposome and lipid-based NPs, have been used to control inflammation in the atheroma microenvironment (see below) [31,53].

Finally, a recent review of plant-derived molecules that represent candidate NP cargo for cardiovascular disease treatment reveals a multitude of molecules that are mostly untested as DNAm modifiers and therefore may provide additional epigenetic weapons to treat AS [54]. Among plant-derived epigenetically active molecules, curcumin attracted considerable attention. An ingredient of Asian cuisine, curcumin has been attributed a range of beneficial effects on human physiology and has been proposed as a potential therapeutic tool for a variety of chronic degenerative diseases [55]. It has been reported that curcumin inhibits DNMT activity [38]. Yet, poor solubility in water and low bioavailability significantly hinder the use of curcumin in experimental medicine. NP technology might bring a solution to that problem, as curcumin loaded to NPs decreased the size and improved markers of stability of the atheroma in a mouse model [39]. Time will tell whether curcumin delivers results as a candidate cardiovascular drug [56].

\subsection{Candidate and Tested NP Delivery Systems in AS}

Conventional lipid-based and polymer-based NPs have been used to successfully mitigate AS in animal models $[57,58]$. A relatively wide panel of molecules that specifically target macrophages and other functionally relevant cell types are available and represent critical components of NP delivery systems. Recent advances in this direction include the administration of the statin simvastatin in liposome NPs, resulting in decreased AS and augmented smooth muscle cell apoptosis in the aorta of a hyperlipidaemic rat model [31]. A significant caveat of that otherwise encouraging study is the potentially negative impact of increased apoptosis on atheroma stability (see concluding section), which will need thorough assessment. Another liposome-based delivery system exploited the liver $\mathrm{X}$ receptor (LXR) agonist GW3965 [32]. LXR agonists deplete the atheroma of lipids by promoting inverse cholesterol transport but, if administered systemically, increase hepatic lipid deposition. The authors demonstrate that GW3965 delivery within liposomes effectively avoids those secondary effects and still decreases AS in a hyperlipidaemic mouse model, thus confirming previous reports [33]. In this case, liposomes were targeted to the atheroma by functionalization with Lyp-1, a cyclic peptide that promotes $\mathrm{p} 32$ receptor-mediated internalization by foam cells. Indeed, peptide-mediated NP targeting has been successfully used in a variety of recent studies. cRGD, a peptidic ligand for integrins present on macrophage and platelet surface, was used to direct anti-inflammatory interleukin-10-loaded pluronic NPs to murine atheroma, resulting in AS mitigation [37]. Another effective targeting peptide is PP1, a ligand for the macrophage scavenger receptor AI [47]. Notably, PP1 binds to both human and murine receptors and thus may help to simplify the transition from animal to human studies. The choice of targeting peptides is not limited to specific receptor ligands. p5RHH undergoes receptor-independent internalization and can be assembled with the mRNA of choice to modify gene expression in the vascular wall [46]. Although not yet tested in vivo, a promising atheroma-targeting peptide is S2P, ligand for the endothelial scavenger receptor STAB2 (aka stabilin-2) [48]. The authors successfully synthesized S2P-conjugated poly(lactic-co-glycolic acid) (PLGA) NPs loaded with the platelet-derived growth factor receptor inhibitor imatinib. Incidentally, PLGA is an interesting topic, as it is a very popular ingredient for NP synthesis and has been recently used to deliver statins to the atheroma $[59,60]$. Yet, at least one study documented a proatherogenic increase in foam cell formation by PLGA NPs in a hyperlipidaemic mouse model, pointing to the need to answer important mechanistic and safety questions before any transition to clinical work can be made [61]. Antibody-mediating receptor targeting has also been successfully used in the case of lipid-based NPs loaded with anti-inflammatory fatty acids and conjugated with antibodies that recognize the endothelial adhesion molecule PECAM-1 [41]. Another example of polypeptide-based delivery system is phospholipid bilayers assembled around an apolipoprotein A-I (ApoA-I) scaffold. The ApoA-I-lipid complex is readily internalized 
by scavenger receptor $\mathrm{BI}$ and is versatile in terms of both lipid composition and nature of hydrophobic load. An obvious advantage of this system is that the NP building blocks have targeting activity per se, besides its exquisitely physiological nature. A recent review covers the applications of ApoA-I-based particles in AS imaging and therapy [42].

Furthermore, non-polypeptidic targeting systems have been developed, particularly carbohydrate-based. Mannose receptors are expressed on macrophage, particularly of the M2 type. A novel mannose-based ligand was engineered that mediated highly efficient endocytosis of NPs in cultured macrophages [45]. Notably, a two-edge mannose-decorated dendrimeric NP delivery system has been developed to simultaneously target the scavenger receptor AI by RNA interference and promote cholesterol efflux with a liver X receptor ligand [62]. Predictably, those NPs significantly decreased AS and atheroma cholesterol load in hyperlipidaemic mice. Another example of carbohydrate-based targeting molecule is hyaluronic acid (HA), a ligand for the CD44 receptor. In one study, HA was both the self-assembling building block and targeting ligand for statin-loaded NPs that significantly decreased atheroma inflammation in mice [43]. A recent review summarizes the virtues of HA as a widely used, well-tolerated NP ingredient [44].

Exciting, cutting-edge technology-based additions to the arsenal of promising delivery systems are macrophage or platelet plasma membrane-coated NPs. The underlying rationale is the natural affinity of those cell types for components of the atheroma. In one elegant study, oxidation-sensitive chitosan oligosaccharide NPs were coated with purified macrophage plasma membranes [34]. The NPs in question combine strong recruitment to the vascular wall due to macrophage mimicry, with specific cargo offload in the reactive oxygen species-rich atheroma, resulting in significant reduction of mouse aortic AS. As for platelet plasma membranes, they were used to coat photosensitizer-loaded upconversion NP cores [35]. This delivery system couples NPs that produce visible light upon near-infrared irradiation and are therefore suitable for deep tissue applications, with the photosensitizer chlorin e6 that generates highly reactive singlet oxygen and cell death upon visible light irradiation. The resulting NPs yielded AS mitigation in animal models, although the caveat of excessive atheroma cell death should be kept in mind (see concluding paragraph). For a recent review of the application of platelet plasma membrane-coated NPs in a range of diseases, see [36]. Interestingly, the studies mentioned in this paragraph creatively exploited reactive oxygen species in two different ways, i.e., as a pre-existing inducers of NP cargo offload in one case and as a consequence of NP cargo activity in the other.

Another promising avenue is the use of recombinant lipoproteins as Trojan horses. In an elegant example, an inhibitor of the interaction between CD40 and its partner tumour necrosis factor receptor-associated factor 6 encapsulated in artificial high-density lipoprotein slowed AS progression without any detectable immune suppression, a known side effect of CD40 signalling [63].

Finally, one interesting approach is the use of $ß$-cyclodextrin NPs. These are cargoswitching NPs that, when presented to the atheroma in a statin-loaded form, incorporate cholesterol and release statins to exert anti-atherogenic effects by compounded statin release and augmented cholesterol efflux [64]. As DNMTi such as SGI-1027 are hydrophobic, Bcyclodextrin NPs could be engineered to achieve a double beneficial effect in the atheroma microenvironment by promoting DNA hypomethylation and cholesterol efflux.

\section{NP-Based DNAm Targeting in Cancer-Associated Inflammation}

Again thanks to Virchow's early work, inflammation is a recognized critical player in cancer; therefore, antitumoral NP-based therapy may identify potentially useful targets in the context of cardiovascular disease [65]. The transcription factor nuclear factor kappa $B$ $(\mathrm{NF} \kappa \mathrm{B})$ is a relevant target in $\mathrm{AS}$, as it is a pivotal player in the proinflammatory response to lipoproteins [66]. NFkB together with the micro-RNA miR-221 and DNMT1 participate in the aetiology of human acute myeloid leukaemia (AML). A recent study documents the effectiveness of gold NPs coated with antagonists of that pathway, in inhibiting DNMT1 and 
thus targeting tumour suppression genes for promoter demethylation and transcriptional reactivation in cultured AML cells [50]. Another study focused on chronic lymphocytic leukaemia (CLL). MiR-29b expression is low in CLL, yet attempts to use it as a therapeutic tool have been frustrated by the many undesired outcomes in non-cancerous tissues. When lipid NPs targeted to specific B cells were used as miR-29b carriers, CLL cell proliferation and survival were reduced both in culture and in a mouse model [67]. Those changes were accompanied by a decrease in DNMT1 and DNA methyltransferase 3A expression, leading to re-expression of crucial tumour suppressor genes. DNMT are not likely direct targets; rather, miR-29b acts on the transcription factor SP1, which, in turn, activates NFKB signalling. Taken together, the two studies mentioned in this paragraph provide evidence that NFKB signalling is perhaps a target of NP-based epigenome modification in inflammatory diseases beyond cancer.

\section{The Other Edge of the Sword: Environmental NPs as Modifiers of the Epigenome}

Although the above-summarised studies are clearly promising, the documented impact of industrial NPs on human health represents a significant caveat that must guide any design of NP-based therapies. The issue is relevant in the context of AS, as the likely use of any effective antiatherogenic NP-based treatment is in relatively lengthy secondary prevention. Humans are exposed to nanomaterials contained in a variety of food, cosmetic, and personal hygiene products. Convincing evidence has linked environmental nanomaterials to cardiovascular disease and other pathologies [68]. One recently documented example is titanium dioxide nanomaterial (TiN). Maternally administered TiN aerosol increases reactive oxygen species and DNAm in mouse foetal hearts [69]. Intriguingly, adult progeny heart DNA was hypomethylated, thus pointing to a marked dynamism of the epigenome in this model. Similarly complex data were obtained in mice exposed to TiN at different ages, demonstrating demethylation in young but not old animals [70]. Additionally, TiN and a range of industrial NPs elicited modest although significant demethylation of significant portions of the genome and DNMT downregulation in a panel of lymphocytic and epithelial cell line surrogates of the physiological airway system [71].

Another relevant finding is myocardial inflammation triggered by carbon NPs in a zebrafish model [72]. Although the work emphasizes environmental exposure to those specific NPs, it suggests caution when designing therapeutic strategies based on carriers chemically related to carbon NPs.

Although the mentioned exposure models pose some unanswered questions and at least two surveys of a panel of metal NPs produced inconclusive data [73,74], the concerns that therapy-oriented NPs might elicit undesired outcomes need to be addressed.

\section{Conclusions and Perspectives}

The idea of improving cardiovascular disease outcome by modifying the epigenome is an exciting one. Basic research is fast deepening our knowledge of the vascular wall epigenome in health and disease, thus pointing to therapeutic targets, whether genomewide or in specific loci. In parallel, NP technology lures with ever-improving strategies for drug/bioactive molecule delivery. On the one hand, advances in the categorization and purification of proteins, peptides, and biologically active molecules will improve NP administration-recognition-release mechanisms. On the other hand, it is likely that novel NPs with geometries beyond the more traditional sphere-cubic, rod, sheet, columnar, tubules, dendrimer, and polymorphous structure (polymeric nanogels) - with unforeseen drug delivery capabilities will be tested [75]. Yet, a number of hurdles are visible on the horizon [76]. One is the choice of DNMTi. Non-nucleoside analogue DNMTi offer the advantage of acting on DNMT directly without the need to be incorporated into DNA [49]. Thus, those molecules should efficiently demethylate DNA in non-proliferating cells such as the endothelium and macrophage, without any gross alteration of genome integrity that could result in apoptosis and atheroma rupture. This last aspect illustrates the profoundly different challenges in NP-based cancer and AS therapy: in the case of 
cancer, cell death in the tumour mass is a desirable outcome, while in AS effective cellular phenotype control must be achieved without disrupting the integrity of the atheroma to avoid its rupture and downstream clinical complications (Figure 1). The future will tell whether non-nucleoside analogue DNMTi will dissipate the doubts raised about their effectiveness and reliability [52]. Furthermore, even if NP-based therapy passes the animal model stage, a variety of issues related to tolerability and long-term effects in humans will have to be answered to. Physical and chemical properties of NPs will have to be finely tuned to assure that off-target effects, thrombosis, blood flow, and immune and allergic responses, to mention just few parameters, are within acceptable range. The potential pitfalls of NP-based modification of the epigenome have been reviewed in detail [77]. A further issue is NP access to the atheroma. Luminal endothelial damage and the presence of microvasculature with poorly developed endothelial lining are landmarks of AS that, in principle, favour NP diffusion to the atheroma by EPR. Recent work using HA NPs showed that this scenario may be too simplistic, as endothelial continuity is unexpectedly recovered in advanced AS of hyperlipidaemic mice, thus decreasing the number of NPs reaching the atheroma [78]. The authors of the study point out that, in contrast to mice, human atheroma microvessels are well-connected to the adventitial vasculature, which should result in overall better NP accessibility to the atheroma. Further exciting work is necessary to appreciate the clinical implications of these findings.

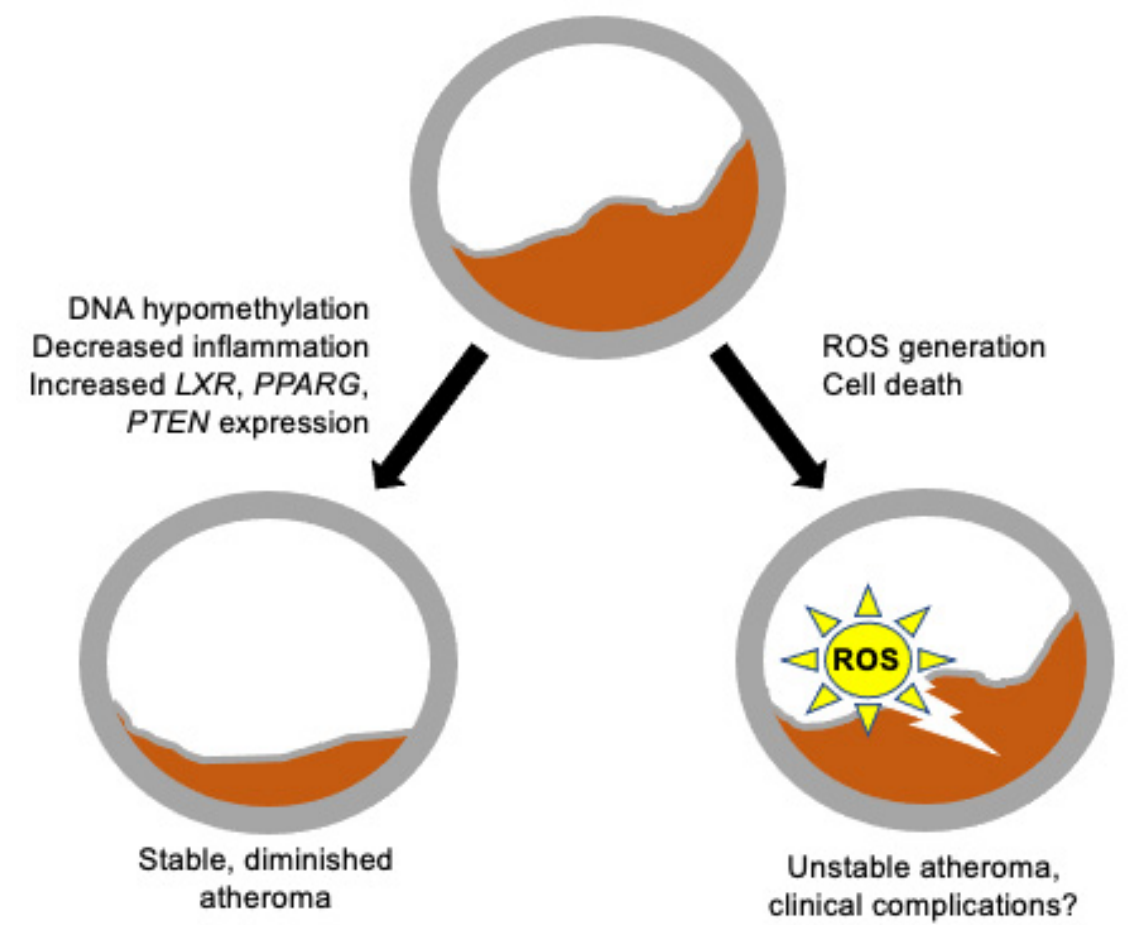

Figure 1. Challenges in NP-based AS therapy. Left, proposed therapeutic strategy consisting of lowering DNA methylation levels close to the ones observed in the unaffected portion of the artery. DNA hypomethylation is accompanied by activation of anti-inflammatory, antiatherogenic gene transcription. Right, cancer therapy-inspired strategy to erode atheroma mass by inducing cell death. The generation of reactive oxygen species (ROS) is presented as an example. Although providing extremely useful insights into mechanism of atherosclerosis, a possible pitfall of strategies aimed at inducing cell death is the risk of atheroma rupture. LXR, liver X receptor; PPARG, peroxisome proliferator-activated receptor gamma; PTEN, phosphatase and tensin homolog.

Author Contributions: Conceptualization, S.Z.; literature search, A.C.M.-S., L.S.-S., and G.L.; writingoriginal draft preparation, S.Z.; writing — review and editing, A.C.M.-S., L.S.-S., and G.L. All authors have read and agreed to the published version of the manuscript. 
Funding: This work was supported by the Mexican National Council for Science and Technology (CONACyT) "Atención a Problemas Nacionales" Programme (grant no. PDCPN-2015-01-584 to S.Z.). CONACyT supported A.C.M.-S. with a Ph.D. Fellowship.

Institutional Review Board Statement: Not applicable.

Informed Consent Statement: Not applicable.

Data Availability Statement: Not applicable.

Conflicts of Interest: S.Z. is currently applying for a relevant patent. All other authors report no conflict of interest.

\section{References}

1. Yetisgin, A.A.; Cetinel, S.; Zuvin, M.; Kosar, A.; Kutlu, O. Therapeutic nanoparticles and their targeted delivery applications. Molecules 2020, 25, 2193. [CrossRef] [PubMed]

2. Kanthi, Y.; de la Zerda, A.; Smith, B.R. Nanotherapeutic Shots through the Heart of Plaque. ACS Nano 2020, $14,1236-1242$. [CrossRef]

3. Rothbart, S.B.; Strahl, B.D. Interpreting the language of histone and DNA modifications. Biochim. Biophys. Acta Gene Regul. Mech. 2014, 1839, 627-643. [CrossRef]

4. Jeltsch, A.; Broche, J.; Bashtrykov, P. Molecular processes connecting dna methylation patterns with DNA methyltransferases and histone modifications in mammalian genomes. Genes 2018, 9, 566. [CrossRef]

5. Greenberg, M.V.C.; Bourc'his, D. The diverse roles of DNA methylation in mammalian development and disease. Nat. Rev. Mol. Cell Biol. 2019, 20, 590-607. [CrossRef]

6. Feinberg, A.P.; Irizarry, R. A Evolution in health and medicine Sackler colloquium: Stochastic epigenetic variation as a driving force of development, evolutionary adaptation, and disease. Proc. Natl. Acad. Sci. USA 2010, 107, 1757-1764. [CrossRef] [PubMed]

7. Franzen, J.; Georgomanolis, T.; Selich, A.; Kuo, C.-C.; Stöger, R.; Brant, L.; Mulabdić, M.S.; Fernandez-Rebollo, E.; Grezella, C.; Ostrowska, A.; et al. DNA methylation changes during long-term in vitro cell culture are caused by epigenetic drift. Commun. Biol. 2021, 4, 598. [CrossRef] [PubMed]

8. Shah, P.K. Inflammation, infection and atherosclerosis. Trends Cardiovasc. Med. 2019, 29, 468-472. [CrossRef] [PubMed]

9. Sniderman, A.D.; Thanassoulis, G.; Glavinovic, T.; Navar, A.M.; Pencina, M.; Catapano, A.; Ference, B.A. Apolipoprotein B particles and cardiovascular disease: A narrative review. JAMA Cardiol. 2019, 4, 1287-1295. [CrossRef] [PubMed]

10. Tabas, I.; Bornfeldt, K.E. Macrophage phenotype and function in different stages of atherosclerosis. Circ. Res. 2016, 118, 653-667. [CrossRef]

11. Libby, P. Inflammation during the life cycle of the atherosclerotic plaque. Cardiovasc. Res. 2021, 117, 2525-2536. [CrossRef] [PubMed]

12. Stavenow, L. Differences in bovine aortic smooth muscle cells cultured from spontaneous atherosclerotic lesions of different severity within the same vessel. Atherosclerosis 1984, 53, 337-342. [CrossRef]

13. Grootaert, M.O.J.; Bennett, M.R. Vascular smooth muscle cells in atherosclerosis: Time for a reassessment. Cardiovasc. Res. 2021, 117, 2326-2339. [CrossRef]

14. Depuydt, M.A.; Prange, K.H.; Slenders, L.; Örd, T.; Elbersen, D.; Boltjes, A.; de Jager, S.C.; Asselbergs, F.W.; de Borst, G.J.; Aavik, E.; et al. Microanatomy of the human atherosclerotic plaque by single-cell transcriptomics. Circ. Res. 2020, 127, 1437-1455. [CrossRef] [PubMed]

15. Libby, P.; Buring, J.E.; Badimon, L.; Hansson, G.K.; Deanfield, J.; Bittencourt, M.S.; Tokgözoğlu, L.; Lewis, E.F. Atherosclerosis. Nat. Rev. Dis. Prim. 2019, 5, 1-18. [CrossRef]

16. Gill, P.K.; Dron, J.S.; Hegele, R.A. Genetics of hypertriglyceridemia and atherosclerosis. Curr. Opin. Cardiol. 2021, 36, $264-271$. [CrossRef]

17. Jaiswal, S.; Natarajan, P.; Silver, A.J.; Gibson, C.J.; Bick, A.G.; Shvartz, E.; McConkey, M.; Gupta, N.; Gabriel, S.; Ardissino, D.; et al. Clonal Hematopoiesis and risk of atherosclerotic cardiovascular disease. N. Engl. J. Med. 2017, 377, 111-121. [CrossRef] [PubMed]

18. Fuster, J.J.; MacLauchlan, S.; Zuriaga, M.A.; Polackal, M.N.; Ostriker, A.C.; Chakraborty, R.; Wu, C.-L.; Sano, S.; Muralidharan, S.; Rius, C.; et al. Clonal hematopoiesis associated with TET2 deficiency accelerates atherosclerosis development in mice. Science 2017, 355, 842. [CrossRef]

19. Sandoval, J.; Heyn, H.; Moran, S.; Serra-Musach, J.; Pujana, M.A.; Bibikova, M.; Esteller, M. Validation of a DNA methylation microarray for 450,000 CpG sites in the human genome. Epigenetics 2011, 6, 692-702. [CrossRef]

20. Moran, S.; Arribas, C.; Esteller, M. Validation of a DNA methylation microarray for 850,000 CpG sites of the human genome enriched in enhancer sequences. Epigenomics 2016, 8, 389-399. [CrossRef]

21. Flores, A.M.; Ye, J.; Jarr, K.U.; Hosseini-Nassab, N.; Smith, B.R.; Leeper, N.J. Nanoparticle therapy for vascular diseases. Arterioscler. Thromb. Vasc. Biol. 2019, 39, 635-646. [CrossRef]

22. Libby, P.; Bornfeldt, K.E. How far we have come, how far we have yet to go in atherosclerosis research. Circ. Res. 2020, 126, 1107-1111. [CrossRef] [PubMed] 
23. Zaina, S.; Heyn, H.; Carmona, F.J.; Varol, N.; Sayols, S.; Condom, E.; Ramirez-Ruz, J.; Gomez, A.; Goncalves, I.; Moran, S.; et al. DNA Methylation Map of Human Atherosclerosis. Circ. Cardiovasc. Genet. 2014, 7, 692-700. [CrossRef]

24. Lund, G.; Andersson, L.; Lauria, M.; Lindholm, M.; Fraga, M.F.; Villar-Garea, A.; Ballestar, E.; Esteller, M.; Zaina, S. DNA methylation polymorphisms precede any histological sign of atherosclerosis in mice lacking apolipoprotein E. J. Biol. Chem. 2004, 279, 29147-29154. [CrossRef] [PubMed]

25. del Pilar Valencia-Morales, M.; Zaina, S.; Heyn, H.; Carmona, F.J.; Varol, N.; Sayols, S.; Condom, E.; Ramírez-Ruz, J.; Gomez, A.; Moran, S.; et al. The DNA methylation drift of the atherosclerotic aorta increases with lesion progression. BMC Med. Genomics 2015, 8, 7. [CrossRef]

26. Peng, J.; Yang, Q.; Li, A.-F.; Li, R.-Q.; Wang, Z.; Liu, L.-S.; Ren, Z.; Zheng, X.-L.; Tang, X.-Q.; Li, G.-H.; et al. Tet methylcytosine dioxygenase 2 inhibits atherosclerosis via upregulation of autophagy in ApoE/mice. Oncotarget 2016, 7, 76423-76436. [CrossRef]

27. Zaina, S.; Gonçalves, I.; Carmona, F.J.; Gomez, A.; Heyn, H.; Mollet, I.G.; Moran, S.; Varol, N.; Esteller, M. DNA methylation dynamics in human carotid plaques after cerebrovascular events. Arterioscler. Thromb. Vasc. Biol. 2015, 35, 1835-1842. [CrossRef] [PubMed]

28. Yu, J.; Qiu, Y.; Yang, J.; Bian, S.; Chen, G.; Deng, M.; Kang, H.; Huang, L. DNMT1-PPAR $\gamma$ pathway in macrophages regulates chronic inflammation and atherosclerosis development in mice. Sci. Rep. 2016, 6, 30053. [CrossRef]

29. Dunn, J.; Qiu, H.; Kim, S.; Jjingo, D.; Hoffman, R.; Kim, C.W.; Jang, I.; Son, D.J.; Kim, D.; Pan, C.; et al. Flow-dependent epigenetic DNA methylation regulates endothelial gene expression and atherosclerosis. J. Clin. Investig. 2014, 124, 3187-3199. [CrossRef]

30. Cao, Q.; Wang, X.; Jia, L.; Mondal, A.K.; Diallo, A.; Hawkins, G.A.; Das, S.K.; Parks, J.S.; Yu, L.; Shi, H.; et al. Inhibiting DNA Methylation by 5-Aza-2'-deoxycytidine ameliorates atherosclerosis through suppressing macrophage inflammation. Endocrinology 2014, 155, 4925-4938. [CrossRef]

31. Wu, J.; Liao, S.; Hu, Q.; Wu, S.; Qiu, S.; Cheng, G.; Li, X.; Lu, W.; Menczel, J.; Bezrukova, A.G. Effects of liposomal simvastatin nanoparticles on vascular endothelial function and arterial smooth muscle cell apoptosis in rats with arteriosclerotic occlusive disease of lower limb via p38 mitogen-activated protein kinase nuclear factor kappa-b pathway. J. Nanosci. Nanotechnol. 2021, 21, 1169-1175. [CrossRef] [PubMed]

32. Benne, N.; Martins Cardoso, R.; Boyle, A.L.; Kros, A.; Jiskoot, W.; Kuiper, J.; Bouwstra, J.; Van Eck, M.; Slütter, B. complement receptor targeted liposomes encapsulating the liver $x$ receptor agonist GW3965 accumulate in and stabilize atherosclerotic plaques. Adv. Healthc. Mater. 2020, 9, e2000043. [CrossRef]

33. Zhang, X.-Q.; Even-Or, O.; Xu, X.; van Rosmalen, M.; Lim, L.; Gadde, S.; Farokhzad, O.C.; Fisher, E.A. Nanoparticles containing a liver $\mathrm{X}$ receptor agonist inhibit inflammation and atherosclerosis. Adv. Healthc. Mater. 2015, 4, 228-236. [CrossRef] [PubMed]

34. Gao, C.; Huang, Q.; Liu, C.; Kwong, C.H.T.; Yue, L.; Wan, J.B.; Lee, S.M.Y.; Wang, R. Treatment of atherosclerosis by macrophagebiomimetic nanoparticles via targeted pharmacotherapy and sequestration of proinflammatory cytokines. Nat. Commun. 2020, 11, 2622. [CrossRef]

35. Ma, Y.; Ma, Y.; Gao, M.; Han, Z.; Jiang, W.; Gu, Y.; Liu, Y. Platelet-mimicking therapeutic system for noninvasive mitigation of the progression of atherosclerotic plaques. Adv. Sci. 2021, 8, 2004128. [CrossRef] [PubMed]

36. Kunde, S.S.; Wairkar, S. Platelet membrane camouflaged nanoparticles: Biomimetic architecture for targeted therapy. Int. J. Pharm. 2021, 598, 120395. [CrossRef]

37. Kim, M.; Sahu, A.; Hwang, Y.; Kim, G.B.; Nam, G.H.; Kim, I.S.; Chan Kwon, I.; Tae, G. Targeted delivery of anti-inflammatory cytokine by nanocarrier reduces atherosclerosis in Apo E/mice. Biomaterials 2020, 226, 119550. [CrossRef] [PubMed]

38. Liu, Z.; Xie, Z.; Jones, W.; Pavlovicz, R.E.; Liu, S.; Yu, J.; Li, P.-k.; Lin, J.; Fuchs, J.R.; Marcucci, G.; et al. Curcumin is a potent DNA hypomethylation agent. Bioorganic Med. Chem. Lett. 2009, 19, 706-709. [CrossRef]

39. Meng, N.; Gong, Y.; Zhang, J.; Mu, X.; Song, Z.; Feng, R.; Zhang, H. A novel curcumin-loaded nanoparticle restricts atherosclerosis development and promotes plaques stability in apolipoprotein E deficient mice. J. Biomater. Appl. 2018, 33, 088532821881532. [CrossRef]

40. Derissen, E.J.B.; Beijnen, J.H.; Schellens, J.H.M. Concise drug review: Azacitidine and decitabine. Oncologist 2013, 18, 619-624. [CrossRef]

41. de Castro Leão, M.; Raffin Pohlmann, A.; Soares Alves, A.; Poiselli Farsky, S.; Uchiyama, M.; Araki, K.; Sandri, S.; Stanisçuaski Guterres, S.; Alves Castro, I. Docosahexaenoic acid nanoencapsulated with anti-PECAM-1 as co-therapy for atherosclerosis regression. Eur. J. Pharm. Biopharm. 2020, 159, 99-107. [CrossRef] [PubMed]

42. Teunissen, A.J.P.; van Leent, M.M.T.; Prevot, G.; Brechbuhl, E.E.S.; Pérez-Medina, C.; Duivenvoorden, R.; Fayad, Z.A.; Mulder, W.J.M. Targeting trained innate immunity with nanobiologics to treat cardiovascular disease. Arterioscler. Thromb. Vasc. Biol. 2021, 41, 1839-1850. [CrossRef] [PubMed]

43. Hossaini Nasr, S.; Rashidijahanabad, Z.; Ramadan, S.; Kauffman, N.; Parameswaran, N.; Zinn, K.R.; Qian, C.; Arora, R.; Agnew, D.; Huang, X. Effective atherosclerotic plaque inflammation inhibition with targeted drug delivery by hyaluronan conjugated atorvastatin nanoparticles. Nanoscale 2020, 12, 9541-9556. [CrossRef] [PubMed]

44. Rao, N.V.; Rho, J.G.; Um, W.; EK, P.K.; Nguyen, V.Q.; Oh, B.H.; Kim, W.; Park, J.H. Hyaluronic acid nanoparticles as nanomedicine for treatment of inflammatory diseases. Pharmaceutics 2020, 12, 931. [CrossRef]

45. Chen, P.; Zhang, X.; Venosa, A.; Lee, I.H.; Myers, D.; Holloway, J.A.; Prud'homme, R.K.; Gao, D.; Szekely, Z.; Laskin, J.D.; et al. A novel bivalent mannosylated targeting ligand displayed on nanoparticles selectively targets anti-inflammatory M2 macrophages. Pharmaceutics 2020, 12, 243. [CrossRef] 
46. Lockhart, J.H.; VanWye, J.; Banerjee, R.; Wickline, S.A.; Pan, H.; Totary-Jain, H. Self-assembled miRNA-switch nanoparticles target denuded regions and prevent restenosis. Mol. Ther. 2021, 29, 1744-1757. [CrossRef]

47. Segers, F.M.; Yu, H.; Molenaar, T.J.; Prince, P.; Tanaka, T.; van Berkel, T.J.; Biessen, E.A. Design and validation of a specific scavenger receptor class AI binding peptide for targeting the inflammatory atherosclerotic plaque. Arterioscler. Thromb. Vasc. Biol. 2012, 32, 971-978. [CrossRef]

48. Esfandyari-Manesh, M.; Abdi, M.; Talasaz, A.H.; Ebrahimi, S.M.; Atyabi, F.; Dinarvand, R. S2P peptide-conjugated PLGAMaleimide-PEG nanoparticles containing Imatinib for targeting drug delivery to atherosclerotic plaques. DARU J. Pharm. Sci. 2020, 28, 131-138. [CrossRef]

49. Datta, J.; Ghoshal, K.; Denny, W.A.; Gamage, S.A.; Brooke, D.G.; Phiasivongsa, P.; Redkar, S.; Jacob, S.T. A new class of quinolinebased dna hypomethylating agents reactivates tumor suppressor genes by blocking DNA methyltransferase 1 activity and inducing its degradation. Cancer Res. 2009, 69, 4277-4285. [CrossRef]

50. Deng, R.; Shen, N.; Yang, Y.; Yu, H.; Xu, S.; Yang, Y.-W.; Liu, S.; Meguellati, K.; Yan, F. Targeting epigenetic pathway with gold nanoparticles for acute myeloid leukemia therapy. Biomaterials 2018, 167, 80-90. [CrossRef]

51. Nguyen, M.A.; Wyatt, H.; Susser, L.; Geoffrion, M.; Rasheed, A.; Duchez, A.C.; Cottee, M.L.; Afolayan, E.; Farah, E.; Kahiel, Z.; et al. Delivery of MicroRNAs by chitosan nanoparticles to functionally alter macrophage cholesterol efflux in vitro and in vivo. ACS Nano 2019, 13, 6491-6505. [CrossRef]

52. Bridgeman, S.; Northrop, W.; Ellison, G.; Sabapathy, T.; Melton, P.E.; Newsholme, P.; Mamotte, C.D.S. Statins do not directly inhibit the activity of epigenetic modifying enzymes. Cancers 2019, 11, 516. [CrossRef]

53. Duivenvoorden, R.; Tang, J.; Cormode, D.P.; Mieszawska, A.J.; Izquierdo-Garcia, D.; Ozcan, C.; Otten, M.J.; Zaidi, N.; Lobatto, M.E.; Van Rijs, S.M.; et al. A statin-loaded reconstituted high-density lipoprotein nanoparticle inhibits atherosclerotic plaque inflammation. Nat. Commun. 2014, 5, 3065. [CrossRef]

54. Hesari, M.; Mohammadi, P.; Khademi, F.; Shackebaei, D.; Momtaz, S.; Moasefi, N.; Farzaei, M.H.; Abdollahi, M. Current advances in the use of nanophytomedicine therapies for human cardiovascular diseases. Int. J. Nanomed. 2021, 16, 3293-3315. [CrossRef] [PubMed]

55. Patel, S.S.; Acharya, A.; Ray, R.S.; Agrawal, R.; Raghuwanshi, R.; Jain, P. Cellular and molecular mechanisms of curcumin in prevention and treatment of disease. Crit. Rev. Food Sci. Nutr. 2020, 60, 887-939. [CrossRef]

56. Kalani, A.; Kamat, P.K.; Kalani, K.; Tyagi, N. Epigenetic impact of curcumin on stroke prevention. Metab. Brain Dis. 2015, 30, 427-435. [CrossRef] [PubMed]

57. Prilepskii, A.Y.; Serov, N.S.; Kladko, D.V.; Vinogradov, V.V. Nanoparticle-based approaches towards the treatment of atherosclerosis. Pharmaceutics 2020, 12, 1056. [CrossRef] [PubMed]

58. Hossaini Nasr, S.; Huang, X. Nanotechnology for targeted therapy of atherosclerosis. Front. Pharmacol. 2021, 12, 755569. [CrossRef]

59. Katsuki, S.; Koga, J.; Matoba, T.; Umezu, R.; Nakashiro, S.; Nakano, K.; Tsutsui, H.; Egashira, K. Nanoparticle-mediated delivery of pitavastatin to monocytes/macrophages inhibits angiotensin ii-induced abdominal aortic aneurysm formation in ApoE/mice. J. Atheroscler. Thromb. 2022, 29, 111-125. [CrossRef] [PubMed]

60. Nenna, A.; Nappi, F.; Larobina, D.; Verghi, E.; Chello, M.; Ambrosio, L. Polymers and nanoparticles for statin delivery: Current use and future perspectives in cardiovascular disease. Polymers 2021, 13, 711. [CrossRef]

61. Yin, T.; Li, Y.; Ren, Y.; Fuad, A.R.M.; Hu, F.; Du, R.; Wang, Y.; Wang, G.; Wang, Y. Phagocytosis of polymeric nanoparticles aided activation of macrophages to increase atherosclerotic plaques in ApoE/mice. J. Nanobiotechnology 2021, 19, 121. [CrossRef]

62. He, H.; Wang, J.; Yannie, P.J.; Korzun, W.J.; Yang, H.; Ghosh, S. Nanoparticle-based "Two-pronged" approach to regress atherosclerosis by simultaneous modulation of cholesterol influx and efflux. Biomaterials 2020, 260, 120333. [CrossRef] [PubMed]

63. Seijkens, T.T.P.; van Tiel, C.M.; Kusters, P.J.H.; Atzler, D.; Soehnlein, O.; Zarzycka, B.; Aarts, S.A.B.M.; Lameijer, M.; Gijbels, M.J.; Beckers, L.; et al. Targeting CD40-induced TRAF6 signaling in macrophages reduces atherosclerosis. J. Am. Coll. Cardiol. 2018, 71, 527-542. [CrossRef] [PubMed]

64. Kim, H.; Kumar, S.; Kang, D.-W.; Jo, H.; Park, J.-H. Affinity-driven design of cargo-switching nanoparticles to leverage a cholesterol-rich microenvironment for atherosclerosis therapy. ACS Nano 2020, 14, 6519-6531. [CrossRef]

65. Schmidt, A.; Weber, O.F. In memoriam of Rudolf virchow: A historical retrospective including aspects of inflammation, infection and neoplasia. Contrib. Microbiol. 2006, 13, 1-15. [CrossRef] [PubMed]

66. Andalibi, A.; Liao, F.; Imes, S.; Fogelman, A.M.; Lusis, A.J. Oxidized lipoproteins influence gene expression by causing oxidative stress and activating the transcription factor NF- $\mathrm{kB}$. Proceedings of the Biochemical Society Transactions. Biochem. Soc. Trans. 1993, 21, 651-655. [CrossRef] [PubMed]

67. Chiang, C.L.; Goswami, S.; Frissora, F.W.; Xie, Z.; Yan, P.S.; Bundschuh, R.; Walker, L.A.; Huang, X.; Mani, R.; Mo, X.M.; et al. ROR1-targeted delivery of miR-29b induces cell cycle arrest and therapeutic benefit in vivo in a CLL mouse model. Blood 2019, 134, 432-444. [CrossRef] [PubMed]

68. Stoccoro, A.; Karlsson, H.L.; Coppedè, F.; Migliore, L. Epigenetic effects of nano-sized materials. Toxicology 2013, 313, 3-14. [CrossRef]

69. Kunovac, A.; Hathaway, Q.A.; Pinti, M.V.; Goldsmith, W.T.; Durr, A.J.; Fink, G.K.; Nurkiewicz, T.R.; Hollander, J.M. ROS promote epigenetic remodeling and cardiac dysfunction in offspring following maternal engineered nanomaterial (ENM) exposure. Part. Fibre Toxicol. 2019, 16, 24. [CrossRef] 
70. Ma, Y.; Guo, Y.; Ye, H.; Huang, K.; Lv, Z.; Ke, Y. Different effects of titanium dioxide nanoparticles instillation in young and adult mice on DNA methylation related with lung inflammation and fibrosis. Ecotoxicol. Environ. Saf. 2019, 176, 1-10. [CrossRef]

71. Lu, X.; Miousse, I.R.; Pirela, S.V.; Melnyk, S.; Koturbash, I.; Demokritou, P. Short-term exposure to engineered nanomaterials affects cellular epigenome. Nanotoxicology 2016, 10, 140-150. [CrossRef]

72. Zhou, W.; Tian, D.; He, J.; Yan, X.; Zhao, J.; Yuan, X.; Peng, S. Prolonged exposure to carbon nanoparticles induced methylome remodeling and gene expression in zebrafish heart. J. Appl. Toxicol. 2019, 39, 322-332. [CrossRef] [PubMed]

73. Brzóska, K.; Grądzka, I.; Kruszewski, M. Silver, Gold, and Iron Oxide Nanoparticles Alter miRNA Expression but do not Affect DNA Methylation in HepG2 Cells. Materials 2019, 12, 1038. [CrossRef] [PubMed]

74. Shoeb, M.; Kodali, V.K.; Farris, B.Y.; Bishop, L.M.; Meighan, T.G.; Salmen, R.; Eye, T.; Friend, S.; Schwegler-Berry, D.; Roberts, J.R.; et al. Oxidative stress, DNA methylation, and telomere length changes in peripheral blood mononuclear cells after pulmonary exposure to metal-rich welding nanoparticles. NanoImpact 2017, 5, 61-69. [CrossRef] [PubMed]

75. Lombardo, D.; Kiselev, M.A.; Caccamo, M.T. Smart Nanoparticles for drug delivery application: Development of versatile nanocarrier platforms in biotechnology and nanomedicine. J. Nanomater. 2019, 2019, 3702518. [CrossRef]

76. Häfner, S.J.; Lund, A.H. Great expectations-Epigenetics and the meandering path from bench to bedside. Biomed. J. 2016, 39, 166-176. [CrossRef]

77. Gedda, M.R.; Babele, P.K.; Zahra, K.; Madhukar, P. Epigenetic aspects of engineered nanomaterials: Is the collateral damage inevitable? Front. Bioeng. Biotechnol. 2019, 7, 228. [CrossRef]

78. Beldman, T.J.; Malinova, T.S.; Desclos, E.; Grootemaat, A.E.; Misiak, A.L.S.; Van Der Velden, S.; Van Roomen, C.P.A.A.; Beckers, L.; Van Veen, H.A.; Krawczyk, P.M.; et al. Nanoparticle-aided characterization of arterial endothelial architecture during atherosclerosis progression and metabolic therapy. ACS Nano 2019, 13, 13759-13774. [CrossRef] [PubMed] 